\title{
KOMPARASI MODEL PEMBELAJARAN INKUIRI TERBIMBING DAN MODEL PEMBELAJARAN BERBASIS MASALAH DITINJAU DARI PEMAHAMAN KONSEP IPA SISWA
}

\author{
Rizqi Hidayat, I Nyoman Suardana, Putri Sarini \\ Program Studi S1 Pendidikan IPA \\ Universitas Pendidikan Ganesha \\ Singaraja, Indonesia \\ e-mail: \{rizqi.hidayat, nyoman.suardana,putri.sarini\}@undiksha.ac.id
}

\begin{abstract}
Abstrak
Penelitian ini bertujuan menganalisis perbedaan pemahaman konsep IPA antara siswa yang dibelajarkan menggunakan model pembelajaran Inkuiri Terbimbing dan model pembelajaran Berbasis Masalah. Penelitian ini adalah penelitian eksperimen semu (quasi experiment) dengan rancangan non-equivalent pretest-posttest control group design. Populasi penelitian ini adalah seluruh siswa kelas VII SMP Negeri 7 Singaraja tahun ajaran 2018/2019 yang terdiri atas 152 siswa dan tersebar ke dalam 5 kelas. Sampel penelitian ini adalah siswa kelas VIID dan kelas VIIE yang dipilih dengan teknik cluster random sampling. Siswa kelas VIID belajar dengan model pembelajaran Inkuiri Terbimbing dan siswa kelas VIIE belajar dengan model pembelajaran Berbasis Masalah. Data penelitian ini adalah pemahaman konsep IPA siswa yang dikumpulkan dengan metode tes pilihan ganda diperluas dan dianalisis menggunakan uji statistik ANCOVA satu jalur dengan taraf signifikansi 0,05 . Hasil penelitian menunjukkan bahwa terdapat perbedaan pemahaman konsep IPA antara siswa yang dibelajarkan menggunakan model pembelajaran Inkuiri Terbimbing dengan siswa yang dibelajarkan menggunakan model pembelajaran Berbasis Masalah. Siswa yang dibelajarkan dan model pembelajaran Inkuiri Terbimbing memiliki pemahaman konsep IPA yang lebih baik dibandingkan dengan siswa yang dibelajarkan dengan model pembelajaran Berbasis Masalah. Hal tersebut ditunjukkan oleh nilai rata-rata posttest siswa yang dibelajarkan menggunakan model pembelajaran Inkuiri Terbimbing dan model pembelajaran Berbasis Masalah secara berturut-turut sebesar 60,4 dan 59,5.
\end{abstract}

Kata kunci: Pemahaman konsep IPA, model pembelajaran Inkuiri Terbimbing, model pembelajaran Berbasis Masalah

\begin{abstract}
This study aims analyze the differences in understanding ability of science concepts students were taught using Guided Inquiry learning models and Problem Based learning models. This research is a quasi experiment with non-equivalent pretest-posttest control group design. The population of this study is all students of class VII SMP Negeri 7 Singaraja academic year 2018/2019 which consists of 152 students and spread into 5 classes. The sample of this research is students of class VIID and class VIIE selected by cluster random sampling technique. VIID students studying with Guided Inquiry learning model and class VIIE Problem Based learning model. The object of this research is students' problem solving abilities of science. Data of students' problem solving abilities of science were collected by test method and analyzed by using one-way Ancova statistic test with significance level of 0.05 . The result shows that there were differences in the understanding science concepts between students who were taught using the Guided Inquiry learning model with students who were taught using Problem-Based learning models. Students who are taught by the guided inquiry learning model have an understanding of the science concept that is better than the students taught by the problem-based learning model. This is indicated by the average posttest value of students who are taught using the Guided Inquiry learning model and the Problem Based learning model in a row of 60.4 and 59.5 .
\end{abstract}

Keywords : Understanding of science concepts, Guided Inquiry learning models, Problem Based learning models. 


\section{PENDAHULUAN}

Pemahaman konsep merupakan kegiatan yang sangat penting dalam pembelajaran karena pemahaman konsep menuntut siswa menemukan sendiri pengetahuannya sehingga proses pembelajaran lebih bermakna. Pemahaman konsep dapat memberikan pengalaman langsung pada siswa sehingga menambah kemampuan dalam mengonstruksi, memahami, dan menerapkan konsep yang telah dipelajari. Pemahaman konsep yang baik akan menyebabkan siswa memiliki ingatan jangka panjang sehingga siswa dapat mengkontruksi pengetahuannya (Triana, dkk 2014).

Berbagai upaya telah dilakukan oleh pemerintah untuk meningkatkan pemahaman konsep IPA siswa di Indonesia, salah satunya adalah menerapkan kurikulum 2013. Kurikulum 2013 ini bersifat student center atau berpusat pada siswa. Kurikulum 2013 dapat memberi kesempatan bagi siswa untuk mengembangkan segala kemampuan yang dimilikinya dalam memecahkan masalah yang dialami saat proses pembelajaran berlangsung. Salah satu mata pelajaran yang penting dalam kurikulum 2013, yaitu ilmu pengetahuan alam (IPA). Pemahaman konsep dipandang sebagai bagian yang sangat penting dari pembelajaran sains (Gok \& Silay, 2010).

Kenyataannya kualitas pendidikan masih jauh dari harapan. Hal tersebut dapat dilihat dari siswa yang masih mengahafal konsep dan kurang mampu menggunakannya saat menemukan masalah dalam kehidupan sehari-hari (Sadia, 2014). Selain itu, rendahnya pemahaman konsep siswa juga dibuktikan dengan rendahnya prestasi yang dicapai siswa Indonesia dalam tes TIMSS. Tes tersebut mengukur tingkatan pengetahuan siswa untuk memecahkan masalah yang sederhana sampai masalah yang memerlukan penalaran tinggi. Berdasarkan hasil TIMSS tahun 2015 menempatkan Indonesia pada peringkat 45 dari 48 negara dengan skor 397. Skor rata-rata sains yang diperoleh menempatkan Indonesia pada predikat low science benchmark yang artinya siswa hanya mampu mengenal sebagian faktafakta dasar dari ilmu sains (Martin, dkk., 2015). Hal serupa juga terlihat dari hasil Program For International Student Asessment (PISA) tahun 2015, Indonesia menduduki 10 peringkat terbawah dari 69 negara yang berpartisipasi (Iswadi, 2016).

Salah satu faktor yang menjadi penyebab rendahnya pemahaman konsep IPA adalah ketidaktepatan guru dalam memilih model pembelajaran yang digunakan saat mengajar dikelas. Proses pembelajaran selama ini masih terkesan hanya berpusat pada guru (teacher oriented) yang menganggap bahwa guru adalah satu satunya sumber utama dan serba tahu, sedangkan siswa hanya menerima informasi yang diberikan oleh guru (Arifin, 2016). Hal tersebut menyebabkan siswa pasif dan tidak berusaha mencari informasi dari sumber lain. Pembelajaran dengan pola ini lebih banyak menekankan pada aspek pengetahuan konsep sedangkan aspek aplikasi, analisis, dan evaluasi hanya mendapat penekanan yang sangat kecil dari pembelajaran yang dilakukan. Siswa kurang dilatih dalam menganalisis, dan mengevaluasi suatu informasi, data, atau argumen sehingga kemampuan berpikir siswa kurang dapat berkembang dengan baik (Widiartini, 2012).

Beberapa model pembelajaran yang dapat meningkatkan pemahaman konsep siswa adalah model pembelajaran Inkuiri Terbimbing dan model pembelajaran Berbasis Masalah. Hal tersebut terlihat dari beberapa hasil penelitian yang menunjukkan keefektifan model pembelajaran Inkuiri Terbimbing dan model pembelajaran Berbasis Masalah terhadap pemahaman konsep siswa. Hasil penelitian Almuntasheri dkk (2016) menyatakan terdapat perbedaan pencapaian pemahaman konsep siswa yang sangat tinggi pada siswa yang belajar dengan inkuiri terbimbing dan pembelajaran langsung. Pembelajaran dengan menggunakan inkuiri terbimbing mampu memberikan kontribusi yang sangat besar terhadap pencapaian 
indikator pemahaman konsep dibandingkan siswa yang belajar dengan menggunakan pembelajaran langsung. Purba (2015) memperoleh hasil penelitian yaitu: (1) ada perbedaan keterampilan proses sains siswa yang dibelajarkan dengan model pembelajaran Problem Based Learning dan model pembelajaran Konvensional. Keterampilan proses sains siswa yang diajarkan dengan model pembelajaran Problem Based Learning lebih baik daripada keterampilan proses sains siswa yang diajarkan dengan model pembelajaran Konvesional. (2) ada perbedaan keterampilan proses sains siswa yang mempunyai pemahaman konsep tinggi dan pemahaman konsep rendah. (3) ada interaksi antara model pembelajaran dan pemahaman konsep terhadap keterampilan proses sains siswa. Keterampilan proses sains siswa yang diajarkan dengan model Problem Based Learning dipengaruhi juga oleh pemahaman konsep, sedangkan keterampilan proses sains siswa yang diajarkan dengan model pembelajaran konvensional tidak dipengaruhi oleh pemahaman konsep siswa. Kajian ini manjadi acuan dalam upaya penelitian Problem Based Learning terhadap pemahaman konsep siswa.

Model pembelajaran inkuiri bersifat student centerd karena model ini memberikan lebih banyak kesempatan bagi siswa untuk mengembangkan selfconcept yang lebih baik. Siswa diharapkan dapat menemukan jawaban dari suatu permasalahan yang ingin dipecahkan melalui model pembelajaran inkuiri. Hal ini sesuai dengan teori belajar kontruktivisme yang dikembangkan oleh Piaget yaitu pengetahuan akan bermakna jika dicari dan ditemukan sendiri oleh siswa (Dahar, 2012).

Dalam pembelajaran inkuiri terbimbing guru tidak melepas begitu saja kegiatan-kegiatan yang dilakukan oleh siswa. Guru harus memberikan pengarahan dan bimbingan kepada siswa dalam melakukan kegiatan-kegiatan sehingga siswa yang berfikir lambat atau siswa yang mempunyai intelegensi rendah tetap mampu mengikuti kegiatan-kegiatan yang sedang dilaksanakan oleh sebab itu guru harus memiliki kemampuan mengelola kelas yang bagus (Dahar, 2012).

Langkah pembelajaran model inkuiri yang diterapkan dalam penelitian ini meliputi menyajikan pertanyaan atau masalah, membuat hipotesis, merancang percobaan, melakuakan percobaan untuk memperoleh data, mengumpulkan dan mengolah data, serta membuat kesimpulan (Sanjaya, 2013)

Sejalan dengan hal tersebut menyatakan bahwa Model pembelajaran berbasis masalah merupakan model pembelajaran yang dalam penerapannya siswa dalam kelompok diminta memecahkan suatu masalah bersama, dan mempresentasikan hasil pemecahan masalah tersebut (Rusman, 2010). Model pembelajaran berbasis masalah membantu siswa untuk menunjukkan dan memperjelas cara berfikir serta kekayaan dari struktur dan proses kognitif yang terlibat didalamnya.

Beberapa ciri penting dari model pembelajaran berbasis masalah sebagai berikut. (1) Tujuan pembelajaran dirancang untuk dapat merangsang dan melibatkan pembelajaran (siswa) dalam pola pemecahan masalah, (2) sifat masalah yang disajikan dalam proses pembelajaran adalah berlanjut, (3) adanya presentasi permasalahan, (4) guru berperan sebagai tutor dan fasilitator, (5) model pembelajaran berbasis masalah dapat digunakan untuk mengembangkan karakter keterampilan berpikir kreatif, dan (6) model pembelajaran berbasis masalah dapat digunakan untuk mengembangkan karakter siswa (Sadia, 2014).

Berdasarkan kajian tersebut, perlu dilakukan penelitian lebih lanjut tentang komparasi model pembelajaran Inkuiri Terbimbing dan model pembelajaran Berbasis Masalah terhadap pemahaman konsep IPA siswa.

\section{METODE}

Penelitian ini adalah penelitian eksperimen semu (quasi experiment) dengan rancangan non-equivalent pretest posttest control group design. Populasi 
dalam penelitian ini adalah seluruh siswa kelas VII SMP Negeri 7 Singaraja tahun ajaran 2018/2019 yang berjumlah 152 siswa dan terdistribusi ke dalam lima kelas. Pengambilan sampel dilakukan dengan teknik cluster random sampling untuk menentukan kelas eksperimen 1 dan kelas eksperimen 2.

Data dalam penelitian ini adalah pemahaman konsep IPA siswa. Data pemhaman konsep IPA dikumpulkan menggunakan metode tes dengan bentuk tes pilihan ganda diperluas. Tes ini digunakan untuk mengukur pemahaman konsep IPA awal siswa (pretest) dan pemahaman konsep IPA akhir siswa (posttest). Tes pemahaman konsep IPA siswa sebanyak 25 butir diuji coba terlebih dahulu dan dipilih 20 butir tes yang memenuhi kriteria. Karakteristik tes yang digunakan dalam penelitian ini adalah tes yang reliabel, konsisten, memiliki daya beda dengan kualifikasi sedang sampai baik sekali, dan memiliki tingkat kesukaran tes dengan kualifikasi sedang dan sukar.

Metode analisis data penelitian ini menggunakan dua teknik, yaitu analisis deskriptif dan analisis inferensial. Analisis deskriptif digunakan untuk mengetahui serta mendeskripsikan nilai rata-rata pretest dan posttest sedangkan analisis inferensial digunakan untuk menguji hipotesis menggunakan uji $\mathrm{F}$ Ancova satu jalur dengan taraf signifikansi 0,05. Sebelum pengujian hipotesis, dilakukan uji asumsi meliputi uji normalitas, uji homogenitas, uji linieritas dan keberartian arah regresi, serta uji homogenitas kemiringan garis regresi (uji interaksi).

\section{HASIL DAN PEMBAHASAN Hasil}

Secara umum hasil penelitian yang dideskripsikan pada bagian ini yaitu nilai rata-rata pretest dan posttest, nilai ratarata pemahaman konsep secara lebih rinci, pengujian asumsi, dan pengujian hipotesis.

Nilai rata-rata pretest digunakan untuk mengukur pemahaman konsep IPA awal siswa sedangkan nilai rata-rata posttest digunakan untuk mengukur pemahaman konsep IPA akhir siswa.
Perbandingan nilai rata-rata pretest dan nilai rata-rata posttest disajikan pada Gambar 1.

$\square$ Inkuiri Terbimbing $\square$ Pembelajaran Berbasis Masalah

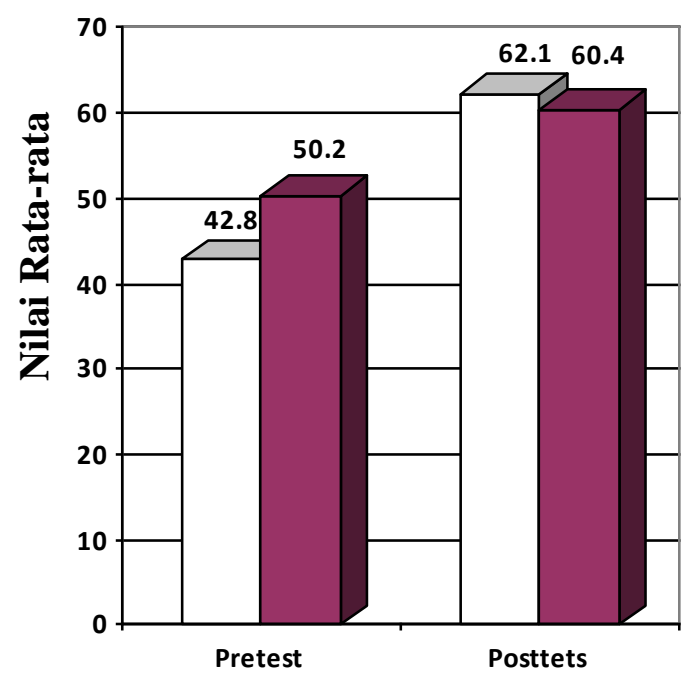

Gambar 1. Perbandingan nilai rata-rata pretest dan nilai rata-rata posttest

Nilai rata-rata pretest siswa menunjukkan nilai yang berbeda pada kedua kelas, yaitu 42,8 pada kelas eksperimen 1 siswa yang dibelajarkan menggunakan model pembelajaran Inkuiri Terbimbing dan 50,2 pada kelas eksperimen 2 siswa yang dibelajarkan menggunakan model pembalajaran Berbasis Masalah. Setelah diberikan perlakuan berupa penerapan model pembelajaran yang berbeda pada masingmasing kelas, nilai rata-rata posttest siswa menunjukkan bahwa nilai rata-rata kelas eksperimen 1 lebih tinggi daripada kelas eksperimen 2, yaitu 60,4 kelas eksperimen 1 dan 59,5 pada kelas eksperimen 2 . Hal tersebut mengindikasikan bahwa model pembelajaran Inkuiri Terbimbing lebih baik untuk meningkatkan pemahaman konsep IPA siswa daripada model pembelajaran Berbasis Masalah.

Secara lebih rinci nilai rata-rata pemahaman konsep IPA dideskripsikan berdasarkan indikatornya. Perbandingan nilai rata-rata pemahaman konsep IPA pada masing-masing indikator disajikan pada Gambar 2. 


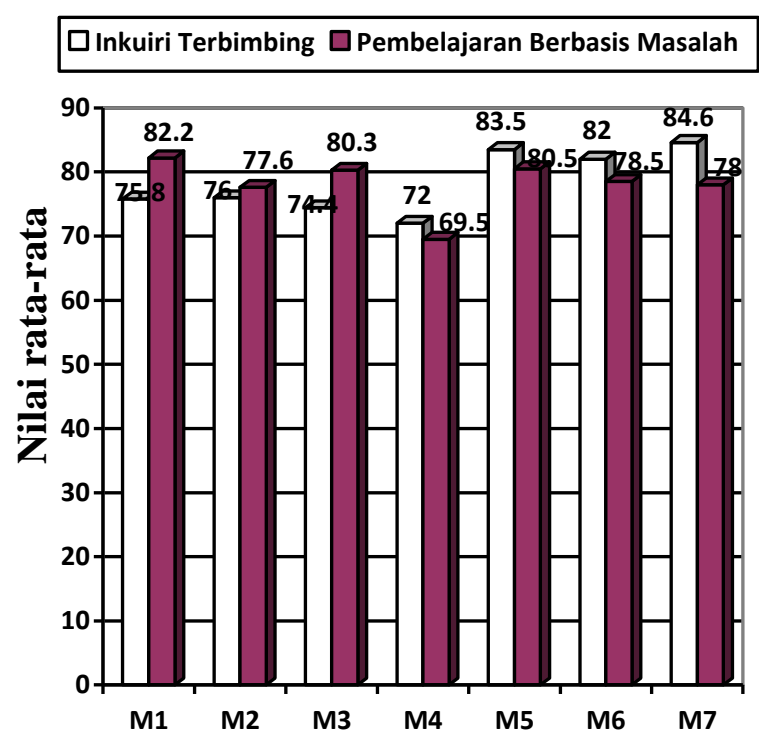

Gambar 2. Perbandingan nilai rata-rata pemahaman konsep IPA

Keterangan :

M1:Menafsirkan

M2:Mencontohkan
M3:Mengklasifikasikan

M4:Merangkum

M5:Menyimpulkan

M6:Membandingkan

M7:Menjelaskan

Nilai rata-rata seluruh indikator pemahaman konsep IPA siswa pada kelas eksperimen 1 lebih tinggi daripada kelas eksperimen 2. Nilai-nilai tersebut mengindikasikan bahwa pemahaman konsep IPA siswa pada kelas eksperimen 1 lebih baik daripada kelas eksperimen 2 .

Sebelum uji hipotesis, dilakukan beberapa uji asumsi. Hasil uji asumsi menunjukkan bahwa data telah memenuhi syarat, yaitu berdistribusi normal, memiliki varian yang homogen, memiliki hubungan yang linier antara pretest dan posttest, serta tidak terdapat interaksi antara pemahaman konsep awal (variabel kovariat) dengan model pembelajaran. Hasil uji asumsi disajikan pada Tabel 1, Tabel 2, Tabel 3, Tabel 4, dan Tabel 5.

Tabel 1. Ringkasan Hasil Uji Normalitas Data

\begin{tabular}{|c|c|c|c|c|c|c|c|}
\hline \multirow[t]{2}{*}{$\begin{array}{c}\text { Unit } \\
\text { Analisis }\end{array}$} & \multirow[t]{2}{*}{ Kelas } & \multicolumn{3}{|c|}{$\begin{array}{c}\text { Kolmogorov- } \\
\text { Smirrnov }\end{array}$} & \multicolumn{3}{|c|}{ Shapiro-Wilk } \\
\hline & & Statistic & $\overline{D f}$ & Sig. & Statistic & $\overline{D f}$ & Sig. \\
\hline Nilai & Eksperimen 1 & 0,129 & 32 & 0,190 & 0,949 & 32 & 0,131 \\
\hline Pretest & Eksperimen 2 & 0,130 & 24 & 0,200 & 0,928 & 24 & 0,089 \\
\hline Nilai & Eksperimen 1 & 0,115 & 32 & 0,200 & 0,942 & 32 & 0,87 \\
\hline Posttest & Eksperimen 2 & 0,173 & 24 & 0,062 & 0,919 & 24 & 0,055 \\
\hline
\end{tabular}

Berdasarkan hasil analisis, diketahui bahwa angka signifikansi yang diperoleh seluruh data lebih besar dari 0,05 . Hal ini mengindikasikan bahwa data nilai pretest dan nilai posttest siswa pada kedua kelas berasal dari populasi yang terdistribusi secara normal.

Tabel 2. Ringkasan Hasil Uji Homogenitas

\begin{tabular}{cccccc}
\hline & & $\begin{array}{c}\text { Levene's } \\
\text { Statistic }\end{array}$ & df1 & df2 & Sig. \\
\hline Pretest & Based on Mean & 2.757 & 1 & 54 & $\mathbf{0 . 1 0 3}$ \\
Posttest & Based on Mean & 0,189 & 1 & 54 & $\mathbf{0 , 6 6 5}$ \\
\hline
\end{tabular}

Berdasarkan hasil analisis, diketahui bahwa angka signifikasi Based on Mean pada nilai pretest dan nilai posttest lebih besar dari 0,05 . Hal ini 
mengindikasikan bahwa varians antar kelas baik pada pretest maupun posttest

adalah sama (homogen).

Tabel 3. Ringkasan Hasil Uji Linieritas dan Keberartian Arah Regresi

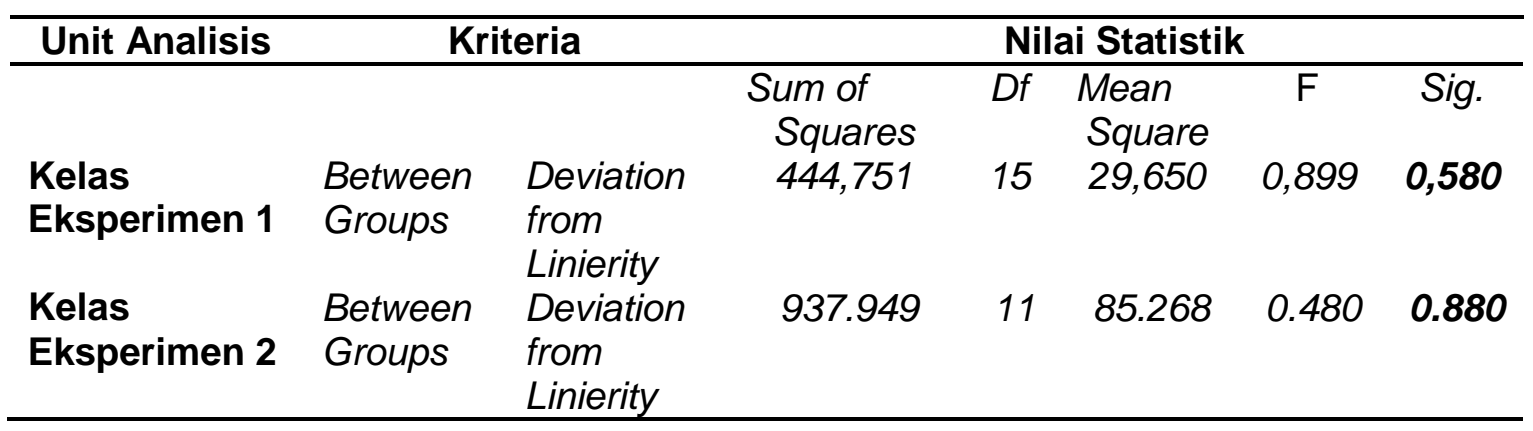

Berdasarkan hasil analisis, hubungan antara pengetahuan awal diketahui bahwa seluruh angka signifikansi (pretest) dan pemahaman konsep IPA pada lajur Deviation from Linierity (posttest) siswa pada masing-masing menunjukkan angka yang lebih besar dari kelas adalah linier.

0,05. Hal ini mengindikasikan bahwa

Tabel 4. Ringkasan Hasil Uji Homogenitas Kemiringan Garis Regresi (Uji Interaksi)

\begin{tabular}{cccccc}
\hline Source & $\begin{array}{l}\text { Type III } \\
\text { Sum of } \\
\text { Squares }\end{array}$ & Df & $\begin{array}{l}\text { Mean } \\
\text { Square }\end{array}$ & F & Sig. \\
\hline $\begin{array}{l}\text { Pengetahuan } \\
\text { Awal * Model } \\
\text { Pembelajaran }\end{array}$ & 5.938 & 1 & 5.938 & 0.194 & 0.662 \\
\hline
\end{tabular}

Berdasarkan hasil analisis, angka signifikansi yang diperoleh pada lajur Pengetahuan Awal*Model Pembelajaran lebih besar dari 0,05. Hal ini mengindikasikan bahwa tidak terdapat interaksi antara kovariat (pemahaman konsep IPA awal siswa) dengan variabel bebas (model pembelajaran). Dengan kata lain, variabel terikat (pemahaman konsep IPA siswa) hanya dipengaruhi oleh variabel bebas (model pembelajaran). Hipotesis penelitian diuji menggunakan uji $\mathrm{F}$ dengan teknik Ancova satu jalur. Hasil uji Ancova secara lengkap disajikan pada Tabel 5.

Tabel 5. Hasil Uji ANCOVA satu jalur

\begin{tabular}{lccccc}
\hline \multicolumn{1}{c}{ Source } & $\begin{array}{l}\text { Type III Sum of } \\
\text { Squares }\end{array}$ & Df & $\begin{array}{c}\text { Mean } \\
\text { Square }\end{array}$ & $\mathrm{F}$ & Sig. \\
\hline Corrected Model & $754,381^{\mathrm{a}}$ & 1 & 754,381 & 9,749 & 0,003 \\
Intercept & 119040,381 & 1 & 119040,381 & 1538,410 & 0,000 \\
Kelas & 754,381 & 1 & 754,381 & 9,749 & $\mathbf{0 , 0 0 3}$ \\
Error & 4178,458 & 54 & 77,379 & & \\
Total & 123705,000 & 56 & & & \\
Corrected Total & 4932,839 & 55 & & & \\
\hline
\end{tabular}


Berdasarkan hasil analisis, angka signifikansi yang diperoleh pada sumber pengaruh model pembelajaran kurang dari 0,05 . Dengan demikian, dapat diputuskan bahwa Ho ditolak dan $\mathrm{Ha}$ diterima. Hal tersebut menunjukkan bahwa terdapat perbedaan pemahaman konsep IPA antara siswa yang dibelajarkan menggunakan model pembelajaran Inkuiri Terbimbing dengan siswa yang dibelajarkan menggunakan model pembelajaran Berbasis Masalah pada siswa kelas VII SMP.

\section{PEMBAHASAN}

Hasil penelitian ini menyatakan bahwa pemahaman konsep siswa yang dibelajarkan dengan model pembelajaran Inkuiri Terbimbing mengalami peningkatan pemahaman konsep lebih tinggi dibandingkan dengan siswa yang dibelajarkan dengan model pembelajaran Berbasis Masalah.

Pengetahuan awal siswa yang diukur menggunakan pretest merupakan variabel kovariat. Nilai rata-rata pretest siswa pada kelas eksperimen 1 dan kelas eksperimen 2 secara berturut-turut 42,8 dan 50,2. Nilai rata-rata yang dapatkan oleh siswa dapat dikendalikan sehingga tidak mempengaruhi pemahaman konsep siswa. Hasil tersebut dipertegas dengan uji interaksi pada pengaruh interaktif antara pengetahuan awal dan model pembelajaran tampak angka signifikansi yang lebih besar dari 0,05 . Hal ini berarti tidak terdapat interaksi antara pengetahuan awal siswa dengan model pembelajaran terhadap pemahaman konsep siswa. Berdasarkan hasil tersebut pemahaman konsep IPA siswa hanya dipengaruhi oleh model pembelajaran setelah dilakukan pengendalian terhadap variabel kovariat. Hal ini sesuai dengan pengertian variabel kovariat yang dinyatakan oleh Trochim (2006), yaitu variabel kovariat adalah variabel yang digunakan untuk menghilangkan atau mengurangi noise pada analisis data yang disebabkan oleh variabel lain selain variabel yang diteliti sehingga efek dari variabel yang diteliti dapat terlihat dengan jelas. Hal tersebut tidak terdapat interaksi antara pengetahuan awal dan model pembelajaran terhadap pemahaman konsep siswa. Hasil rata-rata posttest siswa pada kelas eksperimen 1 dengan model pembelajaran Inkuiri Terbimbing dan kelas eksperimen 2 dengan model pembelajaran Berbasis Masalah secara berturut-turut adalah 60,4 dan 59,5. Nilai rata-rata pada kelas eksperimen 1 memiliki nilai rata-rata lebih tinggi daripada kelas eksperimen 2. Hal tersebut menunjukkan bahwa model pembalajaran Inkuiri Terbimbing lebih efektif digunakan untuk meningkatkan pemahaman konsep IPA siswa daripada model pembelajaran Berbasis Masalah.

Hasil penelitian ini juga diperkuat oleh peneliti yang dilakukan Satyawati dkk, (2015) menyatakan bahwa model pembelajaran Inkuiri Terbimbing mampu memberikan kualifikasi yang lebih baik pada pemahaman konsep siswa dibandingkan dengan model pembelajaran Berbasis Masalah.

Pemahaman konsep siswa pada
kelas eksperimen 1 mengalami
peningkatan lebih tinggi dibandingkan dengan kelas eksperimen 2 karena dalam proses pembelajaran inkuiri terbimbing terdapat kegiatan merumuskan hipotesis. Pada kegiatan ini siswa dapat menjawab sementara dari permasalahan yang ditemukan. Siswa dapat membuat hipotesis berdasarkan pemahaman konsep yang dimiliki melalui proses mencari dan menemukan sendiri informasi tentang materi yang dipelajari sehingga siswa dapat menjelaskan dan menafsirkan hipotesis yang dibuatnya berdasarkan konsep maupun teori yang dipahaminya. Pemahaman siswa tersebut mampu melatih proses berpikir siswa. Hal ini sesuai dengan teori belajar konstruktivisme yang dikembangkan oleh Piaget yaitu pengetahuan akan lebih bermakna jika dicari dan ditemukan sendiri oleh siswa (Dahar, 2011).

Dari hipotesis yang telah dibuat, siswa merancang praktikumnya sendiri. Siswa menentukan alat dan bahan yang digunakan serta langkah kegiatan praktikum yang dilakukan. Kegiatan ini akan melatih pemahaman konsep siswa 
dalam merancang praktikum, siswa harus menguasai konsep-konsep yang berkaitan dengan materi yang dibahas. Jika siswa memiliki pemahaman konsep yang baik maka konsep yang dipahami tersebut akan dapat menuntun siswa dalam menentukan praktikum yang dilakukan. Apabila siswa tidak menguasai konsep, maka siswa akan mengalami kesulitan dalam membuat prosedur praktikum dan melakukan praktikum. Merancang praktikum dapat melatih proses berpikir kreatif siswa sehingga siswa diharapkan mampu mengaitkan teori (konsep) yang dipahami dengan kehidupan sehari-hari. Kegiatan menyusun prosedur praktikum pada mata pelajaran IPA dapat mengembangkan keterampilan berpikir kritis siswa memecahkan masalah, meningkatkan partisipasi belajar siswa, dan meningkatkan berpikir kreatif siswa yang akan berimbas terhadap tingginya pemahaman konsep siswa (Widiartini, dkk, 2011). Ketika siswa merancang praktikum, akan terjadi interaksi pengetahuan yang telah dimiliki siswa dengan lingkungan tempat belajar. Dengan demikian peningkatan kebermaknaan dan ketertarikan terhadap pembelajaran IPA semakin terbangun dengan sendirinya.

Siswa melakukan praktikum dari rancangan yang telah dibuat. Hasil praktikum kemudian dikumpulkan dan dianalisis. Pada kegiatan ini siswa mengumpulkan dan menganalisis data dari praktikum yang telah dilakukan. Siswa melakukan aktivitas menjaring informasi yang dibutuhkan untuk menguji hipotesis yang telah dibuat melalui serangkaian kegiatan percobaan ilmiah yang telah dilakukan. Kegiatan menganalisis data dapat membuat siswa mampu membandingkan hasil yang ditemukan dengan fakta yang ada, dapat mencontohkan dan mengklasifikasikan hal yang ditemukan sesuai dengan permasalahan yang diberikan. Kegiatan ini akan menyebabkan terjadinya interaksi antara pengetahuan yang telah dimiliki sebelumnya dengan pengetahuan atau pengalaman yang baru diperoleh maka akan terjadi interaksi pengetahuan yang telah dimilki siswa dengan lingkungan tempat belajar. Siswa akan selalu berfikir dalam memcahkan suatu masalahmasalah nyata yang berkaitan dengan materi yang diajarkan, sehingga informasi yang siswa peroleh dapat tersimpan lebih lama dalam memori otak siswa (Wardani, 2017). Hal ini membuat pembelajaran yang dialami siswa menjadi lebih bermakna dan akan berdampak pada tingginya pemahaman konsep siswa. Sejalan dengan pendapat Ausubel (Dahar, 2011) yang menyatakan bahwa belajar bermakna hanya terjadi bila siswa menemukan sendiri pengetahuannya. Belajar penemuan yang bermakna sekali hanyalah terjadi pada penelitian yang bersifat imiah. Proses pengumpulan data bukan hanya memerlukan motivasi yang kuat dalam belajar, akan tetapi juga membutuhkan ketekunan dan menggunakan potensi berpikirnya (Sanjaya, 2013). Hal ini sejalan dengan pendapat Bruner (dalam Dahar, 2011) yang menyatakan bahwa belajar penemuan sesuai dengan pencarian pengetahuan secara aktif oleh manusia dengan sendirinya akan memberikan hasil yang paling baik. Berusaha sendiri untuk mencari pemecahan masalah akan menghasilkan pengetahuan yang benarbenar bermakna.

Analisis data yang telah dilakukan kemudian disimpulkan. Saat siswa merangkum seluruh data yang didapat siswa akan menarik kesimpulan untuk menjawab permasalahan yang ditemukan berdasarkan fakta-fakta dan konsepkonsep yang didapatkan sehingga siswa mampu menyimpulkan hasil analisisnya sendiri. Proses ini berimbas terhadap tingginya pemahaman konsep siswa. Hal ini sejalan dengan pendapat (Mladjuna, dkk, 2015) menyatakan bahwa dalam proses menarik kesimpulan siswa akan melibatkan berbagai aspek dalam kemampuan berpikir yaitu berpikir logis, proses induktif, deduktif, evaluatif, memberikan argumen yang logis dalam pengambilan keputusan.

Sejalan dengan hal tersebut model pembelajaran Berbasis Masalah memiliki kontribusi untuk mengembangkan indikator pemahaman konsep siswa, 
diantaranya. Tahap pertama orientasi siswa terhadap masalah. Pada tahap ini guru membagi siswa menjadi beberapa kelompok yang bersifat heterogen. Selanjutnya guru memberikan LKS yang sudah disiapkan kepada setiap kelompok. LKS yang diberikan oleh guru terdapat masalah yang disajikan dalam pembelajaran merupakan permasalahan yang ada dalam kehidupan sehari-hari. Hal tersebut membuat siswa termotivasi untuk belajar serta menggali pengetahuan secara mandiri dan kelompok untuk menyelesaikan permasalahan. Hal serupa diungkapkan oleh Arends (2004) bahwa masalah yang relevan akan membantu anak untuk mencari solusi yang sesuai. Melalui masalah dalam kehidupan seharihari, siswa memiliki kesempatan untuk memecahkan masalah tersebut berdasarkan pengalaman yang mereka miliki. Masalah yang disajikan menuntut siswa untuk mencari solusi dan penyelesaian masalah tersebut. Solusi dari penyelesaian masalah tersebut dicari bersama-sama dengan anggota kelompok yang lain. Hal tersebut menyebabkan siswa fokus pada masalah sehingga motivasi belajarnya akan meningkat. Pada tahap ini mampu mengembangkan indikator pemahaman konsep yaitu menafsirkan.

Tahap kedua, mengorganisasikan siswa untuk belajar. Pada tahap ini siswa mengidentifikasi masalah yang telah disajikan pada LKS dan mencari solusi untuk menyelesaikan masalah tersebut. Penyelesaian masalah yang diberikan oleh guru dilakukan secara berkelompok dengan berbagai peran setiap anggota kelompok untuk menyelesaikan masalah tersebut. Hal tersebut sejalan dengan pendapat Vygotsky menyakini bahwa interaksi sosial dengan teman lain memacu terbentuknya ide baru dan memperkaya intelektua. Perkembangan intelektual terjadi pada saat individu berhadapan dengan pengalaman baru dan menantang, serta ketika mereka berusaha untuk memecahkan masalah yang muncul (Yohanes, 2010). Pada tahap ini mampu mengembangkan indikator pemahaman konsep yaitu menafsirkan, menjelaskan dan mengklasifikasikan. Permasalahan yang diberikan sudah dapat diidentifikasi dan diketahui penyebabnya karena siswa menggali pengetahuannya sendiri dengan mencari informasi dari berbagai sumber, selanjutnya siswa mencoba menemukan masalah utama dari penyebab permasalahan disajikan.

Tahap ketiga, membimbing penyelidikan individu dan kelompok. Pada tahap ini, siswa akan mengeksplorasi pengetahuannya untuk memecahkan masalah yang ada dengan cara mengumpulkan data atau informasi melalui berbagai macam cara untuk menemukan solusi penyelesaian masalah dan melakukan penyelidikan secara berkelompok untuk memecahkan permasalahan yang disajikan. Kegiatan ini didukung oleh paradigma konstruktivistik yang menunjukkan bahwa pembelajaran harus lebih mengutamakan penyelesaian masalah, mengembangkan konsep, kontruksi solusi dan algaritma dibandingkan menghafal prosedur dan menggunakannya untuk memproses suatu jawaban yang benar (Suparno, 1997). Tahap ini, mempersiapkan siswa berpikir tingkat tinggi, analisis dan menemukan dengan menggunakan berbagai macam sumber yang relevan. Pada tahap ini mampu mengambangkan indikator pemahaman konsep yaitu menafsirkan, membandingkan, dan menyimpulkan.

Tahap keempat, mengembangkan dan menyajikan hasil karya, pada tahap ini dapat siswa menentukan penyelesaian masalah yang paling tepat dari berbagai solusi yang mereka temukan. Selanjutnya, siswa menyusun laporan hasil kerja kelompok dalam bentuk gagasan, bagan, dan sebagainya. Pembuatan karya akan melatih siswa untuk berpikir tingkat tinggi karena siswa secara berkelompok harus menyampaikan gagasan untuk mencari solusi dari permasalahan yang ada kemudian akan dibuat hasil karya. Pada tahap ini mampu mengembangkan indikator pemahaman konsep yaitu mencontohkan, merangkum, dan menjelaskan. Berdasarkan hasil perbandingan tersebut, kelas eksperimen 
1 dan kelas eksperimen 2 mampu mengembangkan seluruh tahapan pemahaman konsep. Nilai rata-rata pada kelompok eksperimen 1 lebih besar pada indikator merangkum, menyimpulkan, membandingkan dan menjelaskan. Nilai rata-rata pada kelompok eksperimen 2 lebih besar pada indikator menafsirkan, mencontohkan dan mengklasifikasikan. Artinya penggunaan model pembelajaran Inkuiri Terbimbing lebih baik dalam meningkatkan pemahaman konsep siswa dibandingkan dengan model pembelajaran Berbasis Masalah.

Hasil pemahaman konsep setiap indikator menunjukkan bahwa pada kelas eksperimen 1, indikator menjelaskan memperoleh nilai paling tinggi dan indikator merangkum memperoleh nilai paling rendah. Karena dalam kegiatan pembelajaran inkuiri seperti merumuskan hipotesis, merancang percobaan, dan menyimpulkan membuat siswa terbiasa menyampaikan argumentasi dengan menggunakan konsep yang dipahaminya. Indikator terendah adalah merangkum. Karena proses merangkum hanya dilakukan pada kegiatan menyimpulkan sehingga siswa hanya melatih kegiatan merangkum pada akhir pembelajaran. Meskipun indikator merangkum merupakan indikator terendah namun nilai yang ditunjukkan masih berada pada kategori sedang sehingga hal tersebut menurut peneliti bukanlah sesuatu hal yang buruk dalam pemahaman konsep siswa.

Pada kelas eksperimen 2 indikator
tertinggi terdapat pada indikator menafsirkan dan indikator terendah terdapat pada indikator merangkum. karena dalam proses pembelajaran siswa diberikan permasalahan yang berkaitan dengan lingkungan sekitarnya, kemudian siswa diminta untuk mencari solusi dari permasalahan yang telah diberikan oleh guru. Guru mengawasi dan membimbing siswa dalam menyelesaikan permasalahan yang diberikan. Indikator terendah adalah merangkum. Karena proses merangkum hanya dilakukan pada kegiatan menyimpulkan sehingga siswa hanya melatih kegiatan merangkum pada akhir pembelajaran saja. Meskipun indikator merangkum merupakan indikator terendah namun nilai yang ditunjukkan masih berada pada kategori sedang sehingga hal tersebut menurut peneliti bukanlah sesuatu hal yang buruk dalam pemahaman konsep siswa.

Hasil penelitian ini juga didukung oleh nilai aktivitas belajar siswa yang diperoleh selama proses pembelajaran, siswa pada kelas eksperimen 1 memiliki nilai aktivitas belajar lebih tinggi dibandingkan dengan siswa pada kelas eksperimen 2. Aktivitas belajar siswa pada kelas eksperimen 1 setiap pertemuannya mengalami peningkatan aktivitas belajar. Pertemuan pertama berada pada kriteria aktif, pertemuan kedua sampai seterusnya berada pada kriteria sangat aktif. Hal tersebut membuktikan bahwa aktivitas belajar siswa pada kelas eksperimen 1 adalah sangat aktif. Aktivitas belajar siswa pada kelas eksperimen 2 setiap pertemuannya mengalami peningkatan maupun penurunan aktivitas belajar. Pertemuan pertama sampai ketiga berada pada kriteria aktif, pertemuan keempat sampai kelima berada pada kriteria sangat aktif. Hal tersebut membuktikan bahwa aktivitas belajar siswa pada kelas eksperimen 2 adalah aktif.

Hasil penelitian ini belum tercapai secara maksimal karena terdapat beberapa kendala selama proses pembelajaran di kelas. Adapun kendala yang dialami dalam penelitian ini, yaitu keterbatasan sarana pembelajaran seperti alat dan bahan praktikum. Ketersediaan alat dan bahan praktikum mempengaruhi proses pembelajaran karena alat dan bahan praktikum merupakan sarana untuk melakukan eksperimen. Jika ketersediaan alat dan bahan praktikum terbatas maka tujuan dari kegiatan eksperimen tidak tercapai dengan maksimal. Siswa juga tidak terbiasa mengerjakan LKS yang menuntut pemahaman konsep sehingga siswa sering mengalami kesulitan dalam menentukan solusi yang tepat untuk memecahkan masalah yang terdapat pada LKS.

Beberapa kendala tersebut berusaha diminimalisir dalam penelitian ini 
dengan beberapa cara, yaitu disediakan alat dan bahan praktikum sederhana agar kegiatan praktikum dapat dilaksanakan. Kemudian siswa juga disarankan agar terbiasa membaca petunjuk pengerjaan LKS terlebih dahulu dan memberi pengarahan terkait petunjuk pengerjaan LKS agar pengerjaan LKS lebih terstruktur.

\section{SIMPULAN DAN SARAN}

Mengacu pada rumusan masalah, analisis data dan pembahasan dapat disimpulkan beberapa hal sebagai berikut. Pertama, pemahaman konsep IPA siswa yang dibelajarkan dengan menggunakan model pembelajaran Inkuiri Terbimbing lebih baik dibandingkan dengan model pembelajaran Berbasis Masalah. Kedua, nilai rata-rata indikator pemahaman konsep IPA siswa secara keseluruhan pada kelas eksperimen 1 lebih tinggi daripada kelas eksperimen 2.

Berdasarkan berbagai temuantemuan pada penelitian, maka dapat disarankan beberapa hal dalam upaya meningkatkan pemahaman konsep IPA siswa. Kepada guru bidang studi IPA diharapkan menggunakan model pembelajaran Inkuiri Terbimbing sebagai alternatif pembelajaran dikelas untuk meningkatkan pemahaman konsep IPA siswa. Guru juga diharapkan untuk lebih memperhatikan tujuh indikator - indikator pemahaman konsep, terutama pada indikator yang ditemukan masih rendah.

\section{DAFTAR PUSTAKA}

Almuntasheri, S. Gieles M. N. \& Wright T. 2016. The Effectiveness of a Gided Inquiry-based,

Teachers'

Professiolnal

Development

Programme on Saudi Students' Understanding of Density. Science Education International. Vol. 27 No, 1 (16-39). Terdapat pada http:// files.eric.ed.gov/ fulltext/ EJ1100181.pdf (diakses pada 10 November 2018).

Arifin, Z. 2016. Pengaruh Model Quantum Learning Disertai Metode Eksperimen Terhadap Hasil Belajar Fisika Siswa di SMA Negeri
Kalisat. Jurnal Pembelajaran Fisika, Vol. 4. No 4. Hal 365-370. Tersedia pada https ://m edi a.neliti.com/media/publications/138 969-ID-pengaruh-mo d el-qua ntu m-learn ing-disertai.pdf (diakses tanggal 21 Juni 2018).

Aris, S. 2014. 68 model pembelajaran inovatif dalam kurikulum 2013. Yogyakarta: Ar-Ruzz Media.

Dahar. R. W. 2012. Teori-Teori Belajar. Jakarta: Erlangga

Darwanti, A. 2013. Upaya Peningkatan Hasil Belajar IPA dengan Creative Approach Berbasis Pictorial Riddle Approach pada Siswa Kelas V Sdn 03 Karangsari Jatiyoso Tahun Pelajaran 2012/2013. Skripsi tidak diterbitkan. Surakarta: UMS. Tersedia pada http://e prints .um s.ac.id/23060/21/NASKAH_PUBLI KASI.pdf (diakses tanggal 13 Mei 2019).

Gafur, A. 2003. Penerapan Konsep dan Prinsip Pembelajaran Kontekstual (Contextual $\mathrm{T}$ eaching and Learning) dan Disain Pesan dalam Pengembangan Pembelajaran dan Bahan Ajar. Cakrawala Pendidikan, (3). UNY.

Gunawan, Harjono, A, \& Sutrio. 2015. Multimedia Interaktif Dalam Pembelajaran Konsep Listrik Bagi Calon Guru. Jurnal Pendidikan Fisika dan Teknologi, Vol. 1. No 1. Hal 77-80. Tersedia pada http://jur nalfkip.un ram.ac.id /index. php/JPF T/article/view/230/226 (diakses tanggal 21 Juni 2018). Komalasari, $\quad$ K. 2013. Pembelajaran Kontekstual Konsep dan Aplikasi. Bandung: PT Refika Adiatama.

Komalasari, K. 2013. Pembelajaran Kontekstual : Konsep dan Aplikasi. Bandung: PT Refika Adiatama.

Martin, M. O. et al. 2015. TIMSS 2015 International Result in Science. Tersedia pada timssandpirls.bc. edu/timss2015/international-results /wp-cont ent/ u pl oads/fileba se/fullpdfs/T15-International-Resul 
ts-in-Science-Grade8.pdf (diakses tanggal 30 Juni 2018).

Masganti, S. 2017. Perkembangan Peserta Didik. Medan: Perdana Publishing.

Purba, F. J. 2015. Pengaruh model problem based learning (PBL) dengan pemahaman konsep awal terhadap keterampilan proses sains (KPS) siswa SMA. Jurnal Pendidikan Fisika. Vol 4. No 2. Hal 8-13.

Rusman. $2010 . \quad$ Model-Model Pembelajaran:Mengembangkan Profesionalisme Guru. Jakarta: PT Raja Grafindo Persada.

Sadia, I. W. 2014. Model - model Pembelajaran Sains Konstruktivistik. Yogyakarta: Graha IImu.

Sanjaya, W. 2013. Strategi Pembelajaran Berorientasi Standar Proses Pendidikan. Jakarta: Kencana Paranamedia Group.

Sarnapi. Peringkat pendidikan Indonesia masih rendah. Artikel. 18 Juli 2016. Diakses pada tanggal 20 September 2018, dari http://www.pikiran-rakyat.com/ pendidikan/2016/06/18/ peringkatpendidikan-indonesia-masihrendah- 372187.

Setyawati, Candiasa \& Yudana. 2015. Pengaruh model pembelajaran inkuiri terbimbing terhadap pemahaman konsep dan keterampilan proses sains siswa kelas IX IPA SMA Negeri 2 Kabupaten Badung. ejournal universitas pendidikan ganesha. Terdapat pada https://media.neliti.com/ media/ publications/ 79795-ID-pengaruhmodel-pembelajaran-inkuiriterb.pdf (diakses pada tanggal 3 Desember 2018).

Sugiyanto. $2010 . \quad$ Model-model Pembelajaran Inovatif. Surakarta: Yuma Pustaka.

Suryabrata, S. 2006. Psikologi Pendidikan. Jakarta: PT Rajawali
Triana, Syahrudin, \& Parmiti. 2014. Pengaruh Model Pembelajaran Inkuiri Terbimbing Terhadap Pemahaman Konsep IPA Siswa Kelas V. Mimbar PGSD Undiksha. Vol. 2 No, 1. Hal 34-40. Terdapat padahttp://download.portal.garuda. org/article.php?article $=304043 \&$ val $=1342 \&$ title=pengaruh $\% 20$ model $\%$ 20pembelajaran\%20inkuiri\%terbim bing\%terhadap\%pemahaman\%kon sep\%20ipasiswa\%20kelas\%20v (diakses pada tanggal 25 November 2018).

Trochim, W. M. 2007. The Research Method Knowledge Base. Tersedia pada http://tro chim.hum an.cor nell. Edu $/ \mathrm{kb} /$ index.htm (diakses tanggal 20 Mei 2018).

Widiawati, P. 2015. Analisis Pemahaman Konsep Dalam Pembelajaran IPA Pada Siswa Kelas IV SD DI Gugus II Kecamatan Banjar. Unversitas Pendidikan Ganesha. Vol 3. No, 1. Hal 29-35. Terdapat pada https:// ejournal.undiksha.ac.id/index.php/J JPGSD/article/view/5847 (diakses pada 12 November 2018).

Widiastari. 2017. Komparasi Strategi Pembelajaran Peta Pikiran ( Mind Map) dan Strategi Pembelajaran Peta Konsep (Concept Map) dalam Meningkatkan Hasil Belajar Kimia Siswa. Tugas Akhir tidak diterbitkan. Jurusan Pendidikan Kimia, UNDIKSHA Singaraja.

Widiartini, I A P. 2012. Studi Komparatif Model Pemecahan Masalah dan Pengajuan Masalah Terhadap Motivasi Belajar dan Pemahaman Konsep Kimia Siswa SMA. Tesis tidak diterbitkan. Singaraja: UNDIKSHA 